\title{
Biotensegrity: A Unifying Theory of Biological Architecture With Applications to Osteopathic Practice, Education, and Research-A Review and Analysis
}

Randel L. Swanson II, DO, PhD

From the Department of

Physical Medicine and

Rehabilitation Residency

Program at Temple

University School of

Medicine in Philadelphia,

Pennsylvania. At the time of

submission, Dr Swanson was

performing an osteopathic

traditional rotating internship

at Crozer-Keystone Health

System/Delaware County

Memorial Hospital in

Drexel Hill, Pennsylvania

Financial Disclosures: None reported

Address correspondence to Randel L. Swanson II, DO, $\mathrm{PhD}$, Department of Physical Medicine and Rehabilitation,

Temple University School of Medicine,

3401 N Broad St

Lower Level, Rock Pavilion, Philadelphia, PA 19140-5103.

E-mail: randel

swanson@tuhs.temple.edu

Submitted May 5, 2012 revision receive

July 23, 2012; accepted September 20, 2012.
Since its inception, osteopathic medicine has sought to identify the mechanical causes of disease and to understand the body's structure-function relationship. Research conducted during the past 25 years has demonstrated that the architectural principles of tensegrity can be applied to biological organisms (termed biotensegrity) and that these principles can demonstrate the mechanical structurefunction relationship at all size scales in the human body. Further, biotensegrity at the cellular level allows the cell to mechanically sense its environment and convert mechanical signals into biochemical changes. When applied to the principles of osteopathic medicine, biotensegrity provides a conceptual understanding of the hierarchical organization of the human body and explains the body's ability to adapt to change. Further, biotensegrity explains how mechanical forces applied during osteopathic manipulative treatment could lead to effects at the cellular level, providing a platform for future research on the mechanisms of action of osteopathic manipulative treatment.

J Am Osteopath Assoc. 2013;113(1):34-52

\author{
" On those stepping into rivers staying the same[,] \\ other and other waters flow." \\ - Heraclitus of Ephesus \\ (Doctrine of universal flux, 535-475 BCE) ${ }^{1}$
}

\begin{abstract}
"The molecules that make up cells and the cells that comprise tissues continually turn over; it is maintenance of pattern integrity that we call 'life'. Pattern is a manifestation of structure and structural stability results from establishment of spatial relationships that bring individually destabilized structural elements into balance."

- Donald Ingber, $\mathrm{MD}, \mathrm{PhD}^{2}$
\end{abstract}

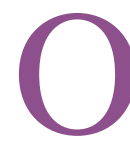
ne of the many important contributions of artist, mathematician, and inventor R. Buckminster Fuller to science was articulating the principles of tensegrity architecture. ${ }^{3,4}$ Unlike typical man-made structures that are stabilized by gravitational compressive forces, tensegrity systems are stabilized by continuous tension, with discontinuous compression..$^{3-5}$ Applications of tensegrity architecture can be seen throughout our world today, from geodesic dome buildings ${ }^{6}$ to deployable structures used by the National Aeronautics and Space Administration, or NASA, for space exploration. ${ }^{7}$ But perhaps the most notable aspect of tensegrity architecture lies in its application to biological organisms. ${ }^{8}$

Research during the past 30 years, spearheaded by Donald Ingber, $\mathrm{MD}, \mathrm{PhD}$, has demonstrated that cells function as independent prestressed tensegrity structures. ${ }^{9-17}$ Further, molecules, ${ }^{18,19}$ tissues,${ }^{20,21}$ organs (bone, ${ }^{22,23}$ heart, ${ }^{24,25}$ lungs ${ }^{26-28}$ ), and even organisms $\mathrm{s}^{22,29-33}$ can all be viewed as tensegrity structures. Within these hierarchical biological tensegrity systems (biotensegrity), the individual prestressed cells are poised and ready to receive mechanical signals and convert them into biochemical changes, termed 
mechanotransduction. ${ }^{24,34,35}$ Tensegrity principles and mechanotransduction are now of crucial importance in our understanding of numerous biological processes, from carcinogenesis ${ }^{36-41}$ to developmental biology ${ }^{21,24,42,43}$ and tissue engineering. ${ }^{20,25,44}$

Scientists from various fields of study are beginning to realize what osteopathic medicine has recognized from its inception: mechanical forces are just as important as biochemical signaling in shaping proper cell development, function, and pathologic processes. At the center of this recognition is an understanding of the hierarchical organization of biological organisms, with biotensegrity being a leading theory. In the present article, I will first define tensegrity architecture and biotensegrity, highlighting the scientific evidence for these concepts. Then, I will introduce the concept of cellular mechanical signal transduction. Finally, I will explore the integration of biotensegrity with osteopathic principles and practice and propose a key role for incorporating biotensegrity principles in osteopathic clinical practice, education, and research.

\section{Principles of Tensegrity}

Tensegrity is an architectural principle put forth by Fuller in the 1960s. ${ }^{3,4}$ Although Fuller formalized the principle of tensegrity architecture, he was inspired by the sculpture "X-Piece," created by artist and sculptor Kenneth Snelson in 1948. ${ }^{5,45}$ According to the tensegrity principle, structures are stabilized by continuous tension (tensional + integrity $=$ tensegrity) with discontinuous compression. In contrast, most manmade structures are stabilized by continuous gravitational compression. For example, Stonehenge maintains its shape on earth because of the compressional force of gravity. If taken into space, the individual stone pieces of Stonehenge would separate and the structure would fall apart. Tensegrity systems, on the other hand, would maintain their shape in the absence of gravity.

According to Fuller, 2 broad classes of tensegrity structures exist: prestressed and geodesic ${ }^{3,4}$ (Figure 1). Prestressed tensegrity structures are formed from a series of discontinuous compression-resistant elements held within a web of continuous tension elements (Figure 1A). These structures can be altered either by adjusting the amount of tensional prestress within the structure or by repositioning the intermittent compression-resistant elements. In contrast, geodesic
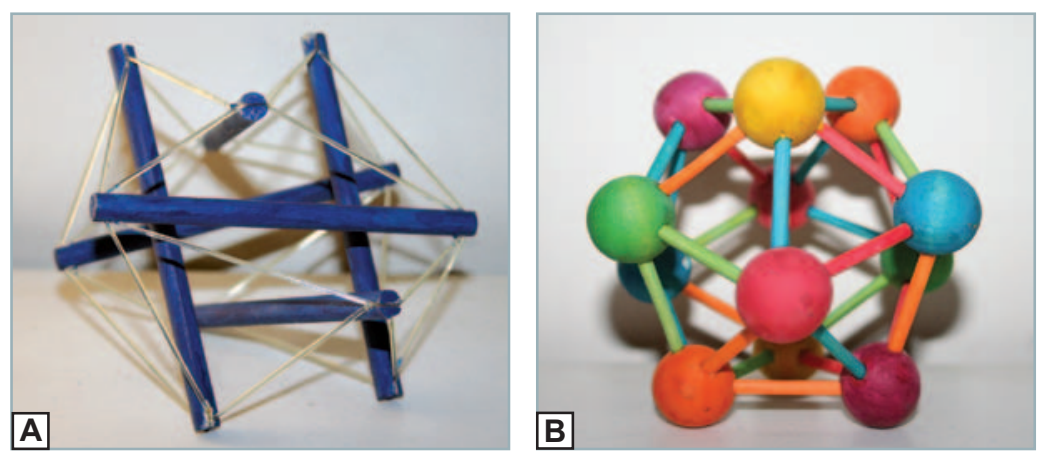

\section{Figure 1.}

Models of (A) prestressed and (B) geodesic tensegrity structures.

The 2 classes of tensegrity systems were founded by R. Buckminster Fuller. 
tensegrity structures are stabilized through force triangulation (Figure 1B). Geodesic structures are also under prestress but differ from prestressed tensegrity systems because the individual elements are capable of alternating between generating tension or resisting compression, depending on how an outside force is applied to the structure. Geodesic tensegrity structures can be altered by adjusting the number and placement of individual tension-compression elements within the system, which also changes the level of resting prestress within the system. ${ }^{22}$ Although Fuller recognized 2 classes of tensegrity structures, mathematical analysis conducted by Robert Connelly, PhD, and Allen Back, $\mathrm{PhD}$, at Cornell University revealed that the same set of mathematical rules define both prestressed and geodesic tensegrity structures. ${ }^{46}$

A number of key elements of tensegrity systems are important in applications to biological organisms. ${ }^{9,10,22}$ Tensegrity structures are intrinsically self-stabilized because of their level of prestress and triangulation. This self-stabilization, in turn, allows tensegrity systems to transfer applied forces throughout their structures, allowing for flexibility while minimizing damage to the structure. Further, because of the prestressed nature of the system, the tensegrity structure immediately resumes its prior shape when an applied force ceases. Finally, the continuous tension with discontinuous compression within tensegrity structures allows them to be extremely efficient, lightweight, and strong.

\section{Application of Tensegrity Theory to Biological Organisms (Biotensegrity)}

Intuition tells us that the spinal column cannot really function as a "column" in any sense of the word. To arrive at this conclusion, all the mind has to do is picture a person holding an advanced back-bend yoga pose such as "The Wheel” (Figure 2). It is not surprising, then, that application of tensegrity architecture to biological organisms (ie, biotensegrity) began with the human spine in the $1970 \mathrm{~s} .{ }^{47}$ In the early 1980 s, scientists began looking at the cell as a tensegrity structure. ${ }^{48}$ Over the next 3 decades, the concept of biotensegrity expanded markedly and today is being applied at the molecular, ${ }^{18,19}$ cellular, ${ }^{2,8-10}$ tissue,,$^{20,21}$ organ,,$^{22-28}$ and organ system ${ }^{22,29-33}$ levels (Figure 3), revealing the true biotensegrity architecture of biological organisms. Further, each "level" is intimately linked to the next in a hierarchical organization, ${ }^{9,22,34,49,50}$ or systems within systems within systems (Figure 4). Without question, the most thoroughly researched area of biotensegrity has been at the cellular level, led by the work of Ingber.

According to Ingber, he was originally introduced to tensegrity architecture in 1975 while he was taking an undergraduate course on sculpting. ${ }^{2}$ Using a prestressed tensegrity model, his professor demonstrated many mechanical properties of tensegrity structures, such as being stabilized by continuous tension with discontinuous compression, being prestressed, responding to external forces by transmitting the force throughout the entire structure, and returning to its original shape on being released from a stretched state. During this time, Ingber was also studying the techniques of cell culture in a biology course. Ingber thought of the tensegrity models from his sculpting course while he was using light microscopy to observe the properties of cells grown in cell culture and their rapid deformation to a rounded-up ball when trypsinized (ie, released from contact with the extracellular matrix [ECM]). Ingber became convinced that cells function mechanically as tensegrity structures, and he went on to pursue graduate work to prove his theory of cellular tensegrity. 


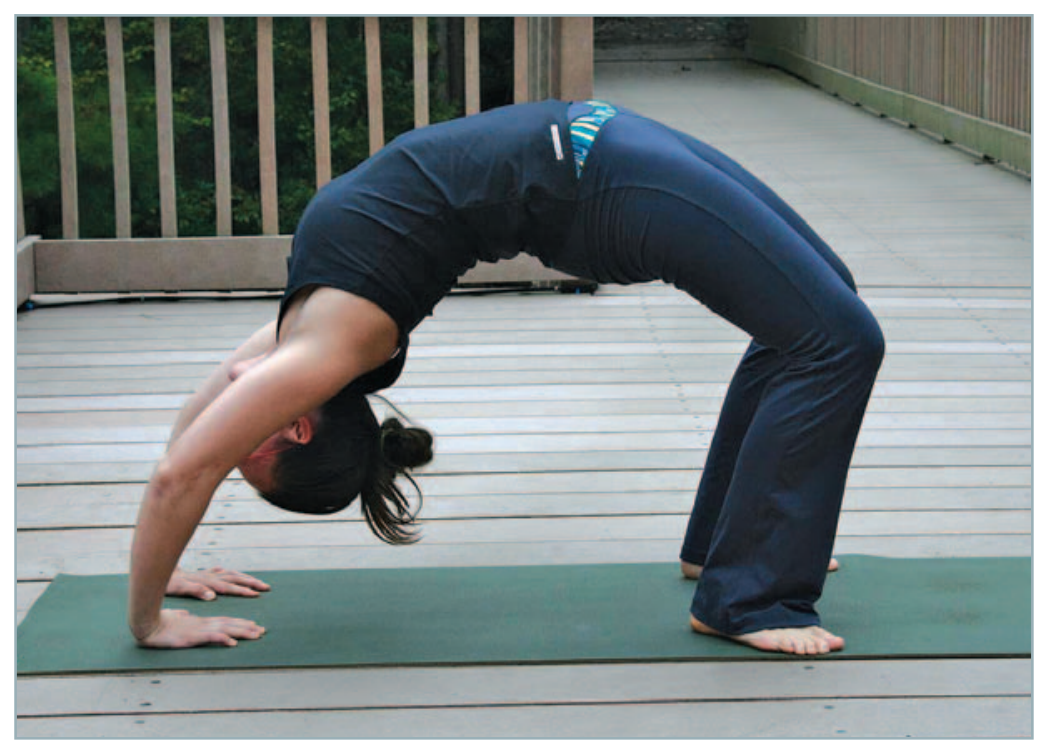

Figure 2.

A person holding the yoga pose "Wheel." This pose demonstrates that the spinal column does not function mechanically as a "column." Printed with permission from the Randel Swanson II, DO, PhD, Collection.

In 1985-10 years after conceiving the concept of cellular tensegrity-Ingber formally introduced his theory in a publication coauthored by his mentor James D. Jamieson, MD, PhD. ${ }^{48}$ Heavily scrutinized in the cell biology world, Ingber established his own laboratory in the mid-1980s and set out to prove that cells functioned as tensegrity structures. Ingber (in addition to others) has since validated his theory of cellular tensegrity through more than 300 scientific publications and more than 40 patents. Moreover, his research has made lasting contributions to the fields of biology, medicine, and engineering. Ingber is now a professor of pathology at Harvard Medical School, as well as a professor of bioengineering at Harvard School of Engineering and Applied Sciences. In January 2009, Ingber was appointed founding director of Harvard University's Hansjörg Wyss Institute for Biologically Inspired Engineering. ${ }^{51}$

\section{Cellular Biotensegrity}

During the past $2 \frac{1}{2}$ decades, novel research techniques have been developed to study cellular mechanics. ${ }^{52}$ With these new techniques, Ingber and others have convincingly demonstrated that cells adhere to the mechanical principles of tensegrity architecture ${ }^{9,10,12}$ and have confirmed the prestressed nature of living cells. ${ }^{14,15,52-56}$
This cellular prestress allows the cell to respond to changing external forces by transmitting the forces throughout the cell, consistent with tensegrity architectural principles. Further, when cells are attached to a flexible extracellular substrate, they pull on the substrate and cause it to wrinkle, demonstrating the transfer of prestress within the cell to the extracellular environment. ${ }^{8,17}$

After Ingber and others established that cells are prestressed, the next step was to identify the tensionproducing and compression-resisting elements within the cell. Initial evidence in the late 1980s and early 1990s compared in vitro biophysical properties of intracellular cytoskeletal components with in vivo immunohistochemical analysis of the cytoskeletal elements. ${ }^{9}$ In vitro, isolated microfilaments (actin stress fibers) appear entangled like a nontensed rope lying on the ground, while hollow microtubules appear straight like a rod or beam. In vivo, microfilaments appear completely straight like a tensed rope and form triangulated geodesic networks within the cell, while microtubules appear bent like a tree bending in the wind. ${ }^{9}$ Consistent with established engineering principles (ie, tension straightens, compression bends), these observations indicated that microfilaments function as tension ele- 


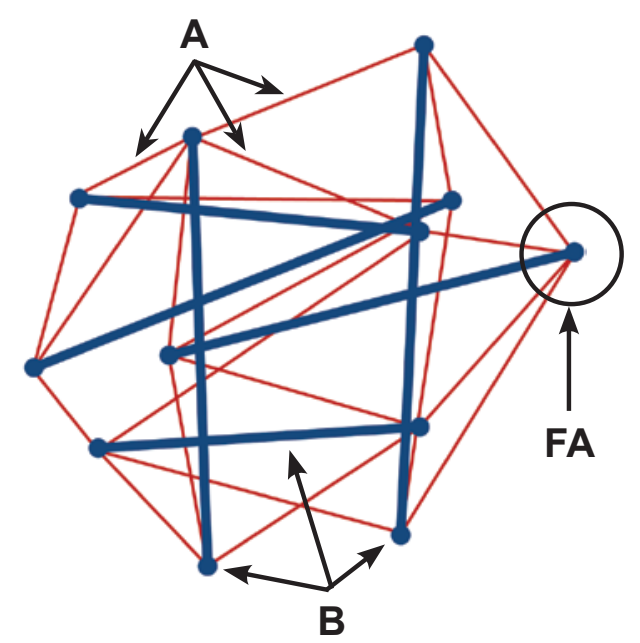

\begin{tabular}{|c|c|c|}
\hline "Level" & Tension (A) & Compression (B) \\
\hline Molecular & Attractive / repulsive forces & $\begin{array}{c}\alpha \text {-helix } \\
\beta \text {-sheet } \\
\text { DNA helix backbone }\end{array}$ \\
\hline Cellular & $\begin{array}{l}\text { Microfilaments } \\
\text { Intermediate filaments }\end{array}$ & $\begin{array}{c}\text { Microtubules } \\
\text { Extracellular matrix }\end{array}$ \\
\hline Tissue & Cells & Extracellular matrix \\
\hline Organ & Lung - fiber system & Ribs \\
\hline $\begin{array}{l}\text { Organ System } \\
\text { (Musculoskeletal) }\end{array}$ & $\begin{array}{l}\text { Muscle } \\
\text { Tendon } \\
\text { Ligaments } \\
\text { Fascia }\end{array}$ & $\begin{array}{l}\text { Bones } \\
\text { Fascia }\end{array}$ \\
\hline
\end{tabular}

Figure 3.

A prestressed tensegrity model that represents biotensegrity architecture at all size scales throughout the human body. Examples of biotensegrity at the molecular, cellular, tissue, organ, and organ system levels with corresponding tension and compression elements are presented. The junction of tension elements with a compression-resistant element can be viewed as a model of a focal adhesion (FA) complex within the cell, which provides the vital link between the extracellular matrix and the cytoskeletal biotensegrity system.

ments and microtubules function as discontinuous compression elements within the cell (Figure 3). ${ }^{9}$ However, direct evidence was still needed. For microfilaments, the direct evidence was provided in 2006 with the use of laser nanoscissor technology that cut microfilaments in living prestressed cells. ${ }^{56}$ After disruption with a laser, microfilaments spontaneously recoiled. ${ }^{56}$ Additional studies ${ }^{15,57}$ supported the theory that microtubules are compression resistant struts inside the cell but suggested that the ECM is also involved in resisting cellular tension. Studies ${ }^{17,53}$ in the twenty-first century have now confirmed that cells are linked to the ECM and that the ECM plays a pivotal role in resisting tensional forces of cells in addition to microtubules. The establishment of a dynamic biophysical connection between cells and their surrounding ECM introduced the possibility of a tensegrity-based hierarchical organization of biological organisms.

A tensegrity model of a cell with a separate tensegrity nucleus intimately connected to the larger tensegrity cell was introduced in Ingber's original 1985 publication on cellular tensegrity. ${ }^{48}$ The model predicts that any force applied to the cell will be transmitted throughout the cell and also to the nucleus, which is itself a tensegrity structure (Figure 4). During the past decade, studies $^{34,49}$ on cultured cells have confirmed that a direct connection from the ECM through the cytoskeleton and down to the nucleus exists and that mechanical forces applied to ECM components are transmitted directly to the cell and nucleus as predicted in hierarchical tensegrity models. The specific link from the ECM to the cell cytoskeleton occurs by means of integrins (transmembrane proteins) clustered together to form focal adhesion complexes, which couple proteins of the ECM to the microtubules and microfilaments that form the cytoskeletal tensegrity system. ${ }^{58}$ Focal adhesion complexes can be thought of as points of integration between tension elements and compression elements at the cellular biotensegrity level (Figure 3). In addition, intermediate filaments (rope-like fibers composed of various proteins depending on the given cell type, which function as tension elements) provide a direct connection from focal adhesion complexes to the nucleus. ${ }^{50}$ Taken together, cellular experiments provide convincing evidence of at least a 3-tiered hierarchical organization of biological life (ECM $\leftrightarrow$ cell $\leftrightarrow$ nucleus). 

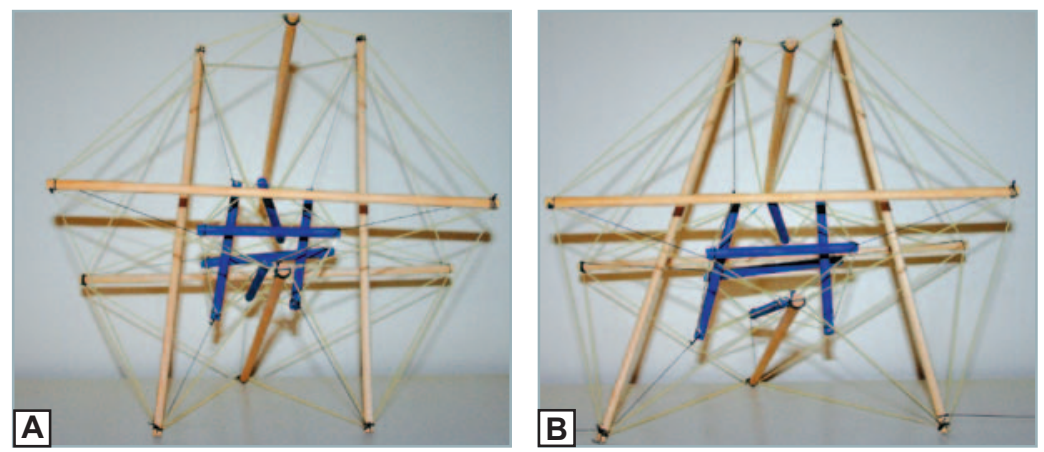

Figure 4.

Model of how a force that is applied to a larger biotensegrity structure will be transmitted throughout the biotensegrity structure at this level (A) and also to the biotensegrity structure at the next level down (B; eg, a cell linked to its nucleus). Printed with permission from the Randel Swanson II, DO, PhD, Collection.

This hierarchical organization has also been supported by whole tissue experiments. For the past decade, neurologist Helene Langevin, MD, has been using in vivo and ex vivo tissue stretch experiments on mouse superficial fascia (subcutaneous areolar tissue) to study fibroblast physiology. Langevin et $\mathrm{al}^{59}$ demonstrated that mouse fibroblasts are intimately connected to their ECM in superficial fascia and spread out in a sheet-like fashion when mechanically stretched both in vivo and ex vivo. Further, Langevin coauthored a report on an increase in the cross-sectional area of the nucleus and a decrease in the number of nuclear membrane invaginations occurring in fibroblasts during ex vivo stretch of mouse superficial fascia. ${ }^{60}$ These results support the findings in cell culture experiments, demonstrating the presence of a true hierarchical organization of biological tissues.

Complementing these laboratory experiments, mathematical modeling of tensegrity systems has been shown to predict numerous aspects of cellular dynamics. ${ }^{13,61}$ In addition, biomedical engineers are using tensegritybased models of red blood cells to begin to understand the cells' ability to constantly deform in circulation while preserving their underlying shape ${ }^{62}$ Further, when modeling individual components of the cellular tensegrity system, researchers discovered that tensegrity models of microfilaments (actin-myosin stress fibers) predict several of their mechanical properties observed in situ. ${ }^{63}$ This research further strengthens the biotensegrity principle of hierarchical organization of biological organismssystems within systems within systems - by demonstrating how a component of a tensegrity system is itself a tensegrity system.

Research on cellular tensegrity has greatly advanced our understanding of cell biology. By viewing the cell as a tensegrity system, scientists can now explain complex behaviors of living cells and understand how cells adapt to their ever-changing mechanical environment. Further, scientists can begin to explain how prestressed cells, linked to the ECM and other cells in hierarchical systems, can convert dynamic mechanical information into biochemical changes through the process of mechanotransduction. Research at the cellular level has provided the backbone upon which application of tensegrity architecture can be applied to all size scales of biological organisms, advancing the concept of biotensegrity. 


\section{Molecular Biotensegrity}

Zanotti and Guerra ${ }^{19}$ proposed that the folding of globular proteins (secondary and tertiary structures) is governed by the principles of tensegrity architecture. According to this hypothesis, $\alpha$-helices and $\beta$-sheets are the compression-resistant struts, while the atomic forces of attraction and repulsion provide the continuous tension (Figure 3). The dynamic conformational changes occurring throughout prestressed globular proteins during ligand binding and release is consistent with tensegrity principles. ${ }^{19}$

On the basis of modeling studies, hierarchical tensegrity mathematical models have accurately predicted numerous properties of cellular actin-myosin stress fibers seen in cultured cells ${ }^{63}$ and can be used to model virus self-assembly. ${ }^{64}$ Further, a model of bacterial carboxysome shells, based on x-ray crystals of the component proteins, revealed that the individual 3-dimensional shapes of the component proteins are pentameric and are able to assemble together to form an icosahedral shell. ${ }^{65}$ This model is another demonstration of hierarchical organization of biotensegrity systems, with the individual prestressed tensegrity globular proteins uniting together to form a larger geodesic tensegrity structure.

At the nucleic acid level, tensegrity principles are being used to construct 3-dimensional tensegrity-based DNA structures. ${ }^{18,66}$ Scientists are exploring the utility of using these self-assembling structures in nanotechnology applications. Thus, at both the nucleic acid level and the protein level, evidence is mounting in support of molecular biotensegrity.

\section{Organ and Tissue Biotensegrity}

With the concept of cellular biotensegrity firmly established, scientists are now studying tissues and organs as tensegrity structures. At the tissue level, most of the research being conducted is aimed at understanding how biotensegrity gives rise to mechanical signal transduction (mechanotransduction) and the role of mechanotrans- duction in tissue development and bioengineering. ${ }^{21,25}$ This topic will be discussed in the following section on cellular mechanical signal transduction. Here, I will limit the discussion to bone and lung. In the context of tensegrity architecture, a bone is a compression-resistant strut as part of the musculoskeletal system. In isolation, however, a bone is also an independent tensegrity structure.

To make this point, Chen and Ingber ${ }^{22}$ looked at the femur. The femur is a long bone with a marrow-filled cavity that is atypical because it has a femoral neck and head that extend superior-medially at an approximately $45^{\circ}$ angle. Because of this anatomy, the gravitational compression force from the weight of the body is not transmitted through the femur as a vertical line. Rather, it is transmitted as a curvilinear force extending from the hip to the knee. As a tensegrity structure, then, the medial aspect of the femur is resisting compression while the lateral aspect is under tension. ${ }^{22}$ Further, at the proximal and distal ends of the femur (and all long bones), the bone widens and compact bone is replaced with cancellous bone. Importantly, cancellous bone is not haphazardly arranged but is organized around geometric triangulation, with some struts under tension and some resisting compression. This triangulation provides maximum stability of the bone and aids in receiving and dissipating force through a joint. Therefore, the femur is a tensegrity structure composed of a combination of prestressed and triangulated components.

The lung is another organ that has been viewed as a tensegrity structure, both in humans ${ }^{28}$ and birds. ${ }^{26}$ According to these models, the lungs are viewed as being under constant tension (prestress). This tension arises from an extensive fiber system that permeates all aspects of the lung, from the lung periphery to the hilum. ${ }^{28}$ The fiber system has a geodesic arrangement with constant tension toward the hilum. During inspiration, the lungs are pulled open because of negative intrathoracic pressure as the diaphragm contracts and because the accessory muscles of respiration pull the ribs 
superior-laterally. In this model, the compression-resistant elements are the ribs. Given the large surface area of the lungs and limited space for supporting tissues, tensegrity architecture provides a support system that is extremely strong and efficient, yet requires minimal space.

\section{Organ System / Organism Biotensegrity}

Application of tensegrity principles to biological organisms began in 1977 when David Robbie, MD, proposed that the human musculoskeletal system could be viewed as a tensegrity system. ${ }^{47}$ Shortly thereafter, the orthopedic surgeon Stevin Levin, MD, began viewing tensegrity as the overall biological support system of the human body, ${ }^{31}$ coining the term biotensegrity. Drawing on experiments at the cellular level, Ingber has also stated numerous times throughout his publications that tensegrity principles apply to all size scales in the human body, including the organism level., ${ }^{9,22,67}$

According to this theory of biotensegrity at the organism level, the bones are the discontinuous compression-resistant struts, while the muscles, tendons, and ligaments are the tension elements. The fascial system is another critical component that can function both as a compression-resistant element and as a tension-generating element. The complete musculoskeletal system then becomes a prestressed biotensegrity system. Movement in the organism arises when a muscle locally increases the amount of tension (prestress) within a given component part of the whole system.

Individual components of the musculoskeletal system have also been viewed as biotensegrity structures. A recent review ${ }^{29}$ has looked at the distal radioulnar joint as a tensegrity structure. Levin ${ }^{31}$ has proposed a tensegrity-based organization of the human pelvis, and several articles $^{22,32,47}$ have suggested that the spinal column is actually a tensegrity structure.

The mammalian spine evolved during millions of years in a horizontal position and relatively recently assumed a vertical position in humans. When one considers the neck of a giraffe in the horizontal position, it becomes obvious that the spine must be stabilized by a mechanism other than gravitational compression. Further, observing a person performing yoga, dance, or gymnastics demonstrates the dynamic movements that are afforded by the spine. Thus, evolution needed to produce a spine that was able to move freely and dynamically, was lightweight, and was self-stabilized while providing sufficient protection to vital neurologic structures. A spine stabilized by the mechanical principles of tensegrity would provide all of these attributes.

Robbie $^{47}$ first hypothesized that the spine could, at times, be stabilized by tensional forces instead of gravitational compression. However, he maintained that the spine could also be stabilized by gravitational compression forces, and that the stability of the spine oscillated between tensegrity and compression, depending on the position of the spine. Levin, ${ }^{32}$ on the other hand, proposed that the spine evolved as a tensegrity structure and functions as such continuously, only resorting to compression-dominated stability during times of disease. Chen and Ingber ${ }^{22}$ also state that only a spine erected as a tensegrity structure would be capable of dynamic motion while also being architecturally stable.

According to tensegrity principles, dynamic motion and stability are 2 properties of prestressed tensegrity structures. The prestress within the spine has been proposed to originate from ligaments, small rotator muscles, and the large erector spinae muscles. Numerous wooden models of tensegrity spines exist (several created by the artist, sculptor, and founder of Intension Designs Ltd, Thomas Flemmons), which demonstrate a tensegrity tower that is self-stabilized by prestress and triangulation and is able to undergo dynamic movements and adapt to changing forces applied throughout the structure.

Although biotensegrity models of the spine are an intuitive representation of the spine as a tensegrity struc- 
ture and aid in understanding the concept, these models are not based on any anatomical arrangement of ligaments and muscle. To my knowledge, no biotensegrity model of the spine incorporates anatomical organization. Further, in contrast to biotensegrity at other levels, a very limited number of experimental studies to date have investigated biotensegrity at the organism level..$^{30}$

\section{Cellular Mechanical Signal Transduction (Mechanotransduction)}

The idea that the building blocks of the biological world are governed by the principles of tensegrity architecture is now well established, with an overwhelming amount of supporting scientific evidence at the cellular level. Importantly, Ingber recognized at the inception of his cellular tensegrity concept that a prestressed cell would be poised and ready to convert mechanical information into biochemical changes. ${ }^{48}$ Research into biotensegrity has now established that prestressed tensegrity cells, linked hierarchically to their extracellular environment and to their nucleus, receive mechanical signals (termed mechanotransduction) and integrate them with other biochemical signals to produce an orchestrated cellular response. ${ }^{24}$ Today, research into mechanotransduction is growing exponentially and is proving to play an important role in fields ranging from developmental biology 68 to pathology. ${ }^{36}$

\section{Components of the Cellular Mechanotransduction System}

While the cell as a whole functions as a prestressed biotensegrity system, extracellular mechanical forces are transduced intracellularly at specific locations within the cell membrane. Research has confirmed that the class of transmembrane proteins known as integrins cluster together to form focal adhesion complexes and then bind to both proteins of the ECM and the cytoskeleton..$^{58,69,70,71}$ Focal adhesions, then, are the mechanical link between the ECM and the cytoskeleton.
Numerous proteins are linked to the intracellular surface of focal adhesions, including both microtubules and microfilaments that are attached as part of the prestressed biotensegrity system. Focal adhesions can be visualized in a tensegrity model as junction points between continuous tension elements and compression-resistant struts (Figure 3). Some of the other proteins linked to focal adhesions include components of the cyclic adenosine monophosphate (cAMP) second messenger system, ${ }^{72,73}$ intermediate filaments that span to the nucleus, ${ }^{50}$ and stress-activated ion channels. ${ }^{74}$ Therefore, focal adhesions can be viewed not only as key components of the cellular biotensegrity system, but also as principle regulators of mechanotransduction.

\section{Cyclic Adenosine Monophosphate}

Cyclic adenosine monophosphate is one of the most ubiquitous second messengers of the cell and performs numerous functions, including protein activation and transcription regulation. Therefore, every medical student studies the details of the G-protein-linked adenylyl cyclase signaling system, which produces cAMP, and the numerous extracellular ligands (including several pharmaceutical agents), which bind to the G-protein and upregulate or downregulate the production of cAMP. In addition to extracellular ligands, it has been demonstrated that mechanical forces applied through focal adhesions can also modulate the production of cAMP and subsequently lead to activation of transcription factors within the nucleus. ${ }^{72,73}$ Thus, mechanical forces play a key role in modulating cellular second messenger signaling.

\section{Mechanical Regulation of Gene Expression}

As predicted in hierarchical tensegrity models (Figure 4), the nucleus has been shown to be intimately linked to the cytoskeleton by both microfilaments and intermediate filaments ${ }^{50}$ and to undergo predictable deformation when extracellular forces are applied to focal adhesions in cultured cells. ${ }^{34,49}$ Within the nucleus, nucleoli have 
been shown to undergo molecular rearrangement when external forces were applied to the focal adhesions, indicating further hierarchical organization of the cell. ${ }^{50}$ Further, ex vivo tissue stretch studies demonstrated a loss of fibroblast nuclear membrane invaginations during tissue stretch, ${ }^{60}$ which is important because these invaginations are thought to play a pivotal role in many key functions of the nucleus-impacting gene expression. Given these findings, it has been proposed that mechanical forces could directly affect genetic expression by regulating the opening and closing of nuclear pore complexes, inducing chromatin remodeling, or lead to melting (opening up) of select regions of DNA. ${ }^{49}$ Research is ongoing in this area.

\section{Ion Channels}

Ion channels represent a third way in which cells communicate. Numerous extracellular and intracellular ligands are known to gait ion channels, and the mechanism of action of several pharmaceutical agents involves modulating the gaiting of these channels. As with the second messenger cAMP, an ion channel has now been discovered that is gaited by mechanical forces. ${ }^{74,75}$ This calcium-selective ion channel (TRPV4) is a member of a relatively new class of ion channels known as stressactivated ion channels. Importantly, TRPV4 was shown to be gated by extracellular mechanical forces applied through focal adhesions, but not by forces applied to other regions of the cell membrane. ${ }^{74}$ This finding indicates that TRPV4 is linked, either directly or indirectly, to focal adhesions, and it further strengthens the evidence that mechanotransduction occurs through focal adhesion complexes.

\section{Applications in Developmental Biology and Tissue Engineering}

It is evident that cells function as biotensegrity structures that are able to receive mechanical signals and integrate those signals with other biochemical signals to modulate second messenger signaling and gene expression. How- ever, the amount of influence these mechanical signals have in controlling cell fate, when compared with other known biochemical signals, was previously unknown less than a decade ago. Evidence is now mounting that contact with the ECM and mechanotransduction may be the most important factors in determining cell fate.

To determine the influence ECM geometry has on cell fate, Ingber set up an experiment on cultured endothelial cells in which he varied the size of ECM "islands" on cell culture dishes. ${ }^{39} \mathrm{He}$ discovered that very small islands caused the cells to undergo apoptosis, while medium-sized islands made the cells quiescent. Large ECM islands, on the other hand, allowed the cells to spread and proliferate. Further, creating long, thin ECM islands allowed endothelial cells to differentiate into capillaries. Expanding on this research, Christopher Chen, MD, $\mathrm{PhD}$, set up an experiment to determine whether ECM geometry could influence stem cell differentiation. ${ }^{76}$ In this experiment, mesenchymal stem cells were cultured in cell dishes containing either very small round ECM islands or large square ECM islands, both containing identical growth media. He discovered that the mesenchymal stem cells cultured on small round ECM islands differentiated into adipocytes, while those stem cells grown on large square ECM islands differentiated into osteoblasts. He went on to further demonstrate that the cells grown on large ECM islands had an increase in the activity of a specific protein (Rho) that led to an increase in cellular prestress. ${ }^{76}$

Numerous research studies have demonstrated a role for mechanical forces during development. ${ }^{21,68}$ One example can be found in lung development. In one study, ${ }^{27}$ biochemical modulation of cellular prestress was shown to alter in vivo mouse lung development. ${ }^{27}$ In another study ${ }^{77}$ fetal rat type 2 epithelial cells were cultured on flexible substrates containing different proteins of the ECM while being subjected to $5 \%$ mechanical strain. The study revealed that the cells maximally expressed markers of type 2 epithelial cell differentiation when 
cultured on laminin substrates, indicating differential mechanotransduction depending on the specific ECM protein available for integrin binding. ${ }^{77}$

With an understanding of how prestressed biotensegrity cells function mechanically and use mechanical signals from their ECM, scientists are developing novel approaches to tissue engineering. ${ }^{20,25,44,78}$ For example, researchers have made dramatic progress in creating a bioartificial lung by using native ECM and mechanical forces ${ }^{79}$ First, a freshly removed rat lung was decullularized using a soap solution (a process that killed all cells and washed away their debris, leaving behind the ECM). The resulting decellularized lung still contained the complete 3-dimensional ECM, including that of the blood vessels and airways. The decellularized lung was seeded with epithelial and endothelial cells and then connected to a machine that ventilated and perfused the lung with liquid (culture medium), as occurs during development. Within 5 days, the researchers were able change the perfusion/ventilation system from cell media to human red blood cells and $98 \% \mathrm{FIO}_{2}$ and were able to demonstrate through analysis of arterial blood gas that the bioartificial lung was being perfused. This research study highlights the fact that, in addition to soluble biochemical signals, the ECM and mechanical forces are just as important in proper tissue differentiation and normal functioning.

\section{Mechanopathology}

The principles of biotensegrity and the role of mechanotransduction in cell physiology lead one to consider the possibility of pathologic states due to altered mechanotransduction. Changes in the extracellular environment or within the cell could lead to altered mechanotransduction and ultimately result in disease. Numerous pathological states, such as cardiomyopathy, osteoporosis, muscular dystrophy, asthma, and atherosclerosis, are now attributed in part to alterations in mechanotransduction. ${ }^{36,80}$

One disease that has received a great deal of attention in relation to mechanotransduction is cancer. ${ }^{36,38-40,81,82}$
Cancer can be viewed as a problem of growth and differentiation. Prestressed biotensegrity cells are able to receive mechanical signals, and this mechanotransduction is known to regulate both growth and differentiation in normally functioning cells. It could be suggested, then, that alterations in mechanotransduction may lead to tumor formation by altering cell growth and differentiation and contribute to the metastatic potential of the resulting tumor by changing the way the tumor cells "sense" or "see" their extracellular environment. ${ }^{36}$

It has long been recognized that the majority of tumors are surrounded by a stiffened or rigid ECM. ${ }^{39,40}$ The increase in ECM stiffness could be due to an extracellular event, such as increased fibrosis, or to an intracellular event, such as an increase in prestress within the cell that is exerting tension on the ECM.$^{36}$ Regardless of the initiating mechanism, the resulting change in the mechanical environment will lead to altered mechanotransduction, which could cause further changes in growth and differentiation and potentially lead to metastasis.

Given the likelihood that abnormal mechanotransduction from altered ECM stiffness or organization likely plays an important role in cancer development, progression, and metastasis, Ingber ${ }^{37}$ suggested that tissue engineering may be able to provide a treatment. He proposed that biomaterials that mimic the embryonic ECM environment may be useful in aiding cells to morph back to their precancer function. This logic can be extrapolated to osteopathic medicine and be used to propose that restoration of physiologic motion after manual treatment for somatic dysfunction could allow cells within the tissue to function optimally by freeing restrictions in mechanotransduction. 


\section{Integration of Biotensegrity} With Osteopathic Principles

Osteopathic medicine's founder, Andrew Taylor Still, MD, DO, stated, "An osteopath, in his search for the cause of diseases, starts out to find the mechanical cause." ${ }^{83}$ In osteopathic medical schools, however, instruction on mechanical forces in pathophysiology typically focuses on the musculoskeletal system and somatic dysfunction, not cellular physiology.

The principles of biotensegrity have numerous applications to osteopathic medicine. From a new understanding of spine mechanics to a more comprehensive understanding of total-body unity, biotensegrity provides a means for osteopathic researchers to conceptualize long-held osteopathic principles and a platform on which the osteopathic profession can build future research. It is therefore surprising that very few mentions of biotensegrity (or simply tensegrity) can be found in the US osteopathic medical literature. ${ }^{84-89}$ In the following sections, I expand on the application of biotensegrity to osteopathic fascial release techniques and propose a new approach to viewing and researching fascial bind and release.

\section{A Biotensegrity Approach to \\ Osteopathic Fascial Release Concepts}

Bind and Release

In his 1902 publication, The Philosophy and Mechanical Principles of Osteopathy, Still declared that the mechanical properties of fascia constitute "one of the greatest problems to solve ... [for] by its action we live and by its failure we die." ${ }^{83}$ The osteopathic medical profession has therefore focused much of its attention on identifying areas of fascial bind and developing therapeutic treatment modalities to release the fascia.

Numerous osteopathic manipulative treatment modalities have been developed to release fascial binds. In the Glossary of Osteopathic Terminology, the word bind is defined as "palpable resistance to motion of an articulation or tissue," while release, or fascial creep, is defined as "the capacity of fascia and other tissue to lengthen when subjected to a constant tension load resulting in less resistance to a second load application." ${ }^{90}$ Osteopathic manipulative treatment techniques that address fascial bind and release generally fall under the category of myofascial release techniques. ${ }^{91}$ One example is fascial unwinding, ${ }^{92}$ which is defined in the Glossary as "a manual technique involving constant feedback to the osteopathic practitioner who is passively moving a portion of the patient's body in response to the sensation of movement. Its forces are localized using the sensations of ease and bind over wider regions." ${ }^{90}$ Another similar technique is known as direct fascial release, ${ }^{91,92}$ which "requires that a torsion, compression, and/or traction force be maintained into the barrier while one waits for a release (fascial creep). After this occurs, the region can move in all planes more easily." ${ }^{91}$ Although the concepts of fascial bind and release are widely accepted in osteopathic medicine, the physiological mechanisms that underlie these phenomena are largely unknown.

\section{Fascial Architecture}

The medical and scientific communities have become increasingly interested in fascia during the past decade, with an exponential increase in the number of scientific publications investigating various aspects of fascia. This interest in fascia culminated with the First International Fascia Research Congress held at Harvard University in 2007, which brought together clinicians and researchers from various specialties in an attempt to develop novel approaches to understanding and researching fascia. Of note, the first presenter at this congress was Ingber, who presented the concepts of cellular tensegrity and mechanotransduction.

Osteopathic medicine has also experienced a resurgence of interest in fascia, with a complete chapter in the new edition of Foundations of Osteopathic Medicine dedicated to the fascial system. ${ }^{93}$ Based largely on the work of anatomist Frank Willard, PhD, this chapter first 
defines fascia as irregular connective tissue of varying densities found throughout the entire body. Then, the chapter explores the architectural arrangement of the fascial system by describing 4 primary subdivisions. This assessment provides a conceptual visualization of the fascial system. However, I propose that biotensegrity is a vital missing component needed to understand fascial architecture and also to understand how mechanical forces can lead to a fascial bind and release.

According to Willard et al, ${ }^{93}$ the 4 primary subdivisions of fascia are superficial (pannicular), axial, meningeal, and visceral. Because fascial release techniques are directed largely toward the superficial and axial layers of fascia, I will focus on these 2 layers. Osteopathic physicians appreciate a direct connection from the skin to the superficial fascia and the superficial fascia to the axial fascia. In the following paragraphs, I will look at the architectural arrangement of this connection and discuss how the irregular connective tissue of the dermis differs from the irregular connective tissue of the superficial and axial fascia.

In histology or pathology, sections of the skin are always taken perpendicular to the skin surface. In this view, the reticular layer of the dermis appears as normal irregular connective tissue with no discernible pattern (Figure 5A). However, a gross view of the reticular dermis horizontal to the surface of the skin shows a regular, geometric pattern of collagen fibers (Figure 5B). Underneath the reticular dermis is the superficial fascia layer (hypodermis in histology), which appears to have numerous fat globules. However, careful removal of the fat globules without disruption of the collagen fibers running between them reveals a geodesic arrangement of collagen fibers that are continuous with the dermis and the axial fascia (Figure 5C). A closer look at the axial fascia reveals a truly irregular appearing prestressed pattern, which is continuous with the epimysium.

As shown in Figure 5, the epidermis, superficial fascia, and axial fascia are arranged hierarchically accord- ing to biotensegrity architecture. Further, every medical student observing his or her first incision during a surgical procedure can immediately see that the skin and fascia are prestressed. ${ }^{94}$ To understand how the level of prestress is maintained and also to investigate possible mechanisms of fascial bind and release, it is necessary to look at the cellular components of the tissue.

\section{Fibroblasts and Mechanotransduction}

Fibroblasts are the principle cells of irregular connective tissue and are responsible for producing the components of the ground substance, as well as collagen, laminin, fibronectin, and other proteins of the ECM. ${ }^{95}$ They also play a vital role in wound healing, where they are recruited to the site of injury, differentiate into myofibroblasts, and participate in closing the wound. ${ }^{96}$ In order to orchestrate the production of these ECM and ground substance components as well as to participate in wound healing, fibroblasts are known to extend long processes in order to participate in cell-to-cell communication. ${ }^{97}$

Cells have been shown to function as prestressed biotensegrity systems connected to proteins of the ECM through focal adhesion complexes and to be poised and ready to receive mechanical signals through the process of mechanotransduction. ${ }^{24}$ In addition, Paul Standley, $\mathrm{PhD}$, has developed an in vitro model of repetitive motion strain and modeled indirect osteopathic manipulative techniques. ${ }^{98}$ Using this model system with human fibroblasts, Standley et al ${ }^{99-102}$ demonstrated an increase in the expression of numerous inflammatory genes and an increase in apoptotic rate in fibroblasts subjected to repetitive motion strain only, when compared with repetitive motion strain plus indirect osteopathic manipulative techniques. In addition, the study by Langevin et $\mathrm{al}^{59}$ on changes in fibroblast morphology during in vivo and ex vivo stretch of mouse superficial fascia to investigate the mechanism of action of acupuncture demonstrated that fibroblasts are connected to their ECM and undergo drastic changes in cell shape during 


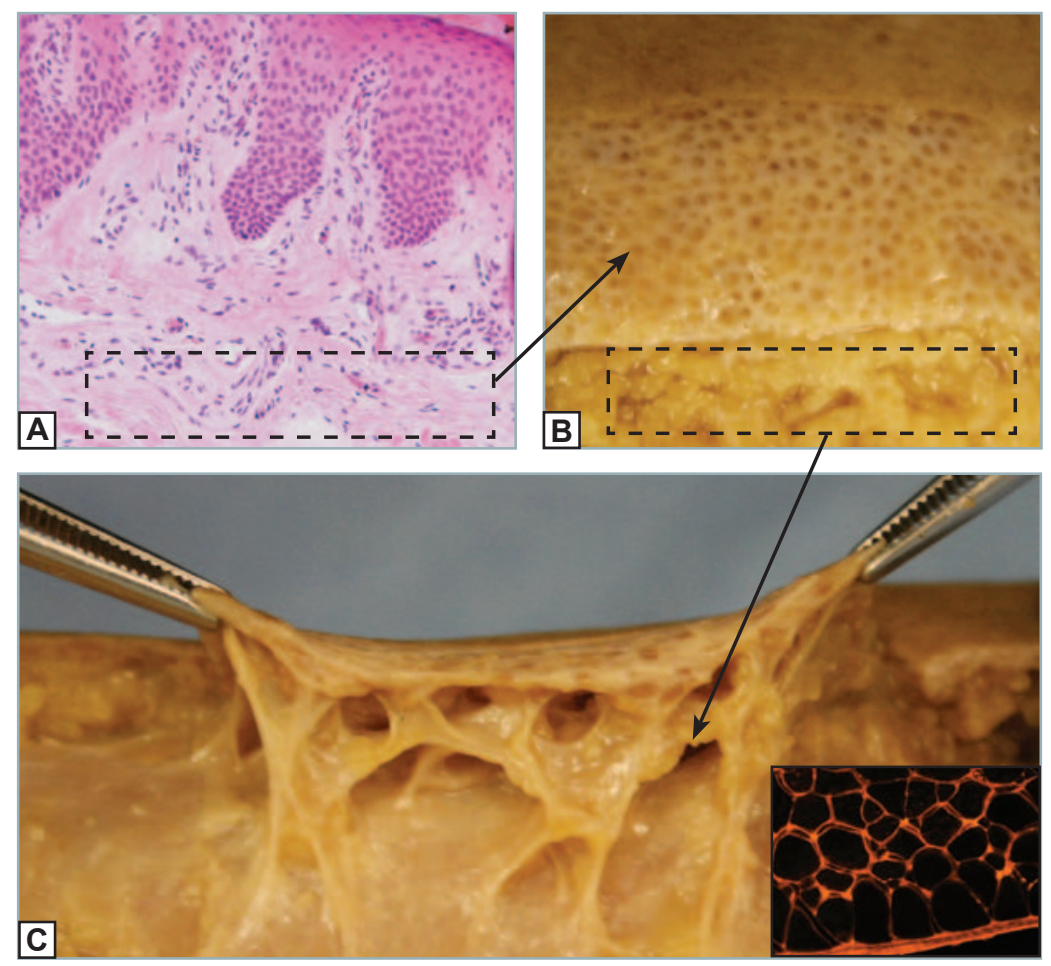

Figure 5.

(A) A hematoxylin and eosin stain of human epidermis and dermis viewed perpendicular to the skin surface. (B) A gross anatomical view of the reticular dermis viewed parallel to the skin surface. Here, the epidermis has been carefully dissected away from the dermis. (C) A gross anatomic view of the superficial fascia with the adipose carefully removed while leaving the collagen fibers intact. This image also demonstrates the interconnection of the epidermis with the axial layer of fascia. The inset in Figure $5 \mathrm{C}$ is an immunohistochemistry image of mouse superficial fascia, which demonstrates the geometric organization of the superficial fascia. Printed with permission from the Randel Swanson II, DO, PhD, Collection.

whole-tissue stretch, as well as changes in nuclear morphology. ${ }^{59,60,103-106}$ Taken together, the work of Standley and Langevin indicates that the fibroblasts of irregular connective tissue are prestressed biotensegrity cells that are linked hierarchically with the ECM of irregular connective tissue (which is also a biotensegrity structure) and are capable of responding to mechanical forces through changes in gene expression.

It has long been held that to generate contractile forces within the connective tissue, fibroblasts need to differentiate into myofibroblasts, as during wound repair. ${ }^{96}$ Therefore, observing fascial contractions in vitro, Robert Schleip, $\mathrm{PhD}$, et $\mathrm{al}^{107}$ hypothesized that fascial contraction in the absence of wound healing may be due to myofibroblast recruitment or differentiation of fibroblasts into myofibroblasts. However, Ingber et al's ${ }^{69}$ research has shown that all cells generate prestress and transfer this prestress to their ECM and that cells are capable of increasing the amount of prestress in response to mechanical forces. Adding to this research, a recent study by Langevin et $\mathrm{al}^{108}$ demonstrated that fibroblasts substantially contribute to the amount of tension (prestress) within superficial fascia and that relaxation of the whole tissue is dependent on fibroblasts altering their cell shape (prestress).

This research demonstrates how fibroblasts can cause, or contribute to the maintenance of, fascial binds by increasing their own prestress and thus increasing prestress within the fascia. Also, the release that occurs during the application of myofascial release techniques may result from fibroblasts sensing the mechanical forces being applied by means of mechanotransduction. The mechanotransduction could then lead to changes in fibroblast prestress, which would decrease the prestress within the fascia. Further, cell-to-cell communication 
between fibroblasts within the fascia could potentially contribute to numerous fibroblasts changing their level of prestress, which would then cause a more robust change in the prestress within the fascia, leading to a palpable release. With the bind released, the normal physiologic motion would be restored within the tissue and the fibroblasts would then return to their normal resting prestress.

\section{A New Approach to Somatic Dysfunction}

On the basis of the principles of biotensegrity described in the present article, I propose a more general approach to somatic dysfunction. Cells need to sense their extracellular environment to survive. When a cell is in contact with its ECM, the physiologic motion of its surrounding tissue will be sensed through mechanotransduction and integrated with other biochemical signals to orchestrate processes such as growth, differentiation, and apoptosis. Restrictions to normal physiologic motion are sensed through mechanotransduction and lead to altered functioning of the cell. This altered functioning could be viewed as acute somatic dysfunction. If the physiologic motion is restored, either through the use of osteopathic manipulative treatment or other means, the tissue returns to its prior state and functions normally. If, however, physiologic motion is not restored, prolonged changes in mechanical forces can lead to chronic somatic dysfunction or fibrosis, which is much more difficult to manage with osteopathic manipulative treatment or other treatment modalities. Future studies are needed to test this hypothesis using the principles of biotensegrity.

\section{Conclusion}

The riddle within Heraclitus' doctrine of universal flux ${ }^{1}$ is that while everything is constantly changing, everything remains the same. The human body has an ability to adapt to its ever-changing environment. The principles of biotensegrity provide an explanation as to how the body can receive constantly changing mechanical forces, disperse these forces throughout the organism, convert them into biochemical signals within the cell, and retain its structural integrity.

As a fundamental architectural building block of biological organisms, biotensegrity can be demonstrated at all size scales within the human body. From molecules and cells to tissues and organs, each level can be viewed as a biotensegrity structure intimately connected in a hierarchical organization with the level above and below. This realization provides the clinician with an explanation as to how forces applied through the skin during osteopathic manipulative treatment could have effects at the cellular level—and possibly even lead to changes in gene expression.

Perhaps the most important aspect of biotensegrity will lie in its application to osteopathic research. Still clearly recognized the importance of research when he stated in his autobiography, "It has been the object of myself and also of my teachers to direct and be guided by the compass that points to nothing but demonstrative truth. ... Give me anything but a theory that you cannot demonstrate." ${ }^{109}$ To this end, the principles of biotensegrity can be used to bridge the gap between basic scientists and osteopathic physicians as we move toward unraveling the mechanisms of action of osteopathic manipulative medicine. 


\section{Acknowledgments}

I thank James E. McHugh, DO, MBA, former director of Osteopathic Medical Education at Delaware County Memorial Hospital in Drexel Hill, Pennsylvania, for his editorial assistance with this article. I also thank Adam C. Gilliss, DO; David C. Mason, DO; Millicent King Channell, DO; Rocco Carsia, PhD; Christine F. Giesa, DO; and Venkat Venkataraman, PhD, for their encouragement and support.

\section{References}

1. Graham DW. Heraclitus. In: Zalta EN, ed. Stanford Encyclopedia of Philosophy. Summer 2011 ed. Stanford, CA: Standford University; 2011. http://plato.stanford.edu/archives/sum2011/entries/heraclitus. Accessed July 22, 2012.

2. Ingber DE. Cellular tensegrity: defining new rules of biological design that govern the cytoskeleton. J Cell Sci. 1993;104(pt 3):613-627. http://jcs.biologists.org /content/104/3/613.long. Accessed April 25, 2012.

3. Fuller RB. Tensegrity. Portfolio Art News Ann. 1961;4:112-127.

4. Fuller RB. Tensile-integrity structures. US patent 3,063,521. November 13, 1962.

5. Pugh A. An Introduction to Tensegrity. Berkeley, CA: University of California Press; 1976.

6. Hopster G. Illustrated Dome Building. Monterey, CA: Hexadome America; 2005.

7. Tibert G. Deployable Tensegrity Structures for Space Applications [doctoral thesis]. Stockholm, Sweden: Department of Mechanics, Royal Institute of Technology; 2002:244.

8. Ingber DE. The architecture of life. Sci Am. 1998;278(1):48-57.

9. Ingber DE. Tensegrity I: cell structure and hierarchical systems biology. J Cell Sci. 2003;116(pt 7):1157-1173. http://jcs.biologists.org/content/116/7/1157.long. Accessed April 25, 2012.

10. Ingber DE. Tensegrity II: how structural networks influence cellular information processing networks. $J$ Cell Sci. 2003;116(pt 8):1397-1408. http://jcs.biologists.org /content/116/8/1397.long. Accessed April 25, 2012.

11. Volokh KY, Vilnay $\mathrm{O}$, Belsky M. Tensegrity architecture explains linear stiffening and predicts softening of living cells. J Biomech. 2000;33(12):1543-1549.
12. Wang N, Naruse K, Stamenovic D, et al. Mechanical behavior in living cells consistent with the tensegrity model. Proc Natl Acad Sci U S A. 2001;98(14):7765-7770. http://www.ncbi.nlm.nih.gov/pmc/articles /PMC35416/?tool=pubmed. Accessed April 25, 2012.

13. Laurent VM, Cañadas $P$, Fodil $R$, et al. Tensegrity behaviour of cortical and cytosolic cytoskeletal components in twisted living adherent cells. Acta Biotheor. 2002;50(4):331-356.

14. Wang N, Tolić-Nørrelykke IM, Chen J, et al. Cell prestress, I: stiffness and prestress are closely associated in adherent contractile cells. Am J Physiol Cell Physiol. 2002;282(3):C606-C616. http://ajpcell.physiology.org/ content/282/3/C606.long. Accessed April 25, 2012.

15. Stamenović D, Mijailovich SM, Tolić-Nørrelykke IM, Chen J, Wang N. Cell prestress, II: Contribution of microtubules. Am J Physiol Cell Physiol. 2002;282(3):C617-C624. http://ajpcell.physiology.org /content/282/3/C617.long. Accessed April 25, 2012.

16. Stamenović D, Mijailovich SM, Tolić-Nørrelykke IM, Wang N. Experimental tests of the cellular tensegrity hypothesis. Biorheology. 2003;40(1-3):221-225.

17. Hu S, Chen J, Wang N. Cell spreading controls balance of prestress by microtubules and extracellular matrix. Front Biosci. 2004;9:2177-2182.

18. Liedl T, Högberg B, Tytell J, Ingber DE, Shih WM Self-assembly of three-dimensional prestressed tensegrity structures from DNA. Nat Nanotechnol. 2010;5(7):520-524. http://www.ncbi.nlm.nih.gov/pmc/articles /PMC2898913/?tool=pubmed. Accessed April 25, 2012.

19. Zanotti G, Guerra C. Is tensegrity a unifying concept of protein folds? FEBS Lett. 2003;534(1-3):7-10. http://www.sciencedirect.com/science/article/pii /S001457930203853X. Accessed April 25, 2012.

20. Ghosh K, Ingber DE. Micromechanical control of cell and tissue development: implications for tissue engineering. Adv Drug Deliv Rev. 2007;59(13):1306-1318.

21. Mammoto T, Ingber DE. Mechanical control of tissue and organ development. Development. 2010;137(9):1407-1420. http://www.ncbi.nlm.nih.gov/pmc/articles /PMC2853843/?tool=pubmed. Accessed April 25, 2012.

22. Chen CS, Ingber DE. Tensegrity and mechanoregulation: from skeleton to cytoskeleton. Osteoarthritis Cartilage. 1999;7(1):81-94.

23. Huang $C$, Ogawa R. Mechanotransduction in bone repair and regeneration. FASEB J. 2010;24(10):3625-3632. http://www.fasebj.org/content/24/10/3625.long. Accessed April 25, 2012.

24. Ingber DE. Tensegrity-based mechanosensing from macro to micro. Prog Biophys Mol Biol. 2008;97(2-3):163-179. http://www.ncbi.nlm.nih.gov/pmc/articles/PMC2570054 /?tool=pubmed. Accessed April 25, 2012. 
25. Parker KK, Ingber DE. Extracellular matrix, mechanotransduction and structural hierarchies in heart tissue engineering. Philos Trans R Soc Lond B Biol Sci. 2007;362(1484): 1267-1279. http://www.ncbi.nlm.nih.gov/pmc/articles /PMC2440395/?tool=pubmed. Accessed April 25, 2012.

26. Maina JN. Spectacularly robust! tensegrity principle explains the mechanical strength of the avian lung. Respir Physiol Neurobiol. 2007;155(1):1-10.

27. Moore KA, Polte T, Huang S, et al. Control of basement membrane remodeling and epithelial branching morphogenesis in embryonic lung by Rho and cytoskeletal tension. Dev Dyn. 2005;232(2):268-281. http://onlinelibrary.wiley.com /doi/10.1002/dvdy.20237/full. Accessed April 25, 2012.

28. Weibel ER. What makes a good lung? Swiss Med Wkly. 2009;139(27-28):375-386. http://www.smw.ch/for-readers /archive/backlinks/?url=/docs/pdfcontent/smw-12270.pdf. Accessed April 25, 2012.

29. Hagert E, Hagert CG. Understanding stability of the distal radioulnar joint through an understanding of its anatomy. Hand Clin. 2010;26(4):459-466.

30. Kassolik K, Jaskólska A, Kisiel-Sajewicz K, Marusiak J, Kawczynski A, Jaskólski A. Tensegrity principle in massage demonstrated by electro- and mechanomyography. J Bodyw Mov Ther. 2009;13(2):164-170.

31. Levin SM. The Icosahedron as a Biologic Support System. Proceedings, 34th Annual Conference on Engineering in Medicine and Biology. 1981;23:404.

32. Levin SM. The tensegrity-truss as a model for spine mechanics: biotensegrity. JMMB. 2002;2(3):375-388.

33. Masi AT, Nair K, Evans T, Ghandour Y. Clinical, biomechanical, and physiological translational interpretations of human resting myofascial tone or tension. Int J Ther Massage Bodywork. 2010;3(4):16-28. http://www.ncbi.nlm.nih.gov/pmc/articles /PMC3088522/?tool=pubmed. Accessed April 25, 2012.

34. Ingber DE. Cellular mechanotransduction: putting all the pieces together again. FASEB J. 2006;20(7):811-827. http://www.fasebj.org/content/20/7/811.long. Accessed April 25, 2012.

35. Alenghat FJ, Ingber DE. Mechanotransduction: all signals point to cytoskeleton, matrix, and integrins. Sci STKE. 2002;2002(119):e6.

36. Jaalouk DE, Lammerding J. Mechanotransduction gone awry. Nat Rev Mol Cell Biol. 2009;10(1):63-73. http://www.ncbi.nlm .nih.gov/pmc/articles/PMC2668954/?tool=pubmed. Accessed April 25, 2012.

37. Ingber DE. Can cancer be reversed by engineering the tumor microenvironment? Semin Cancer Biol. 2008;18(5):356-364. http://www.ncbi.nlm.nih.gov/pmc/articles /PMC2570051/?tool=pubmed. Accessed April 25, 2012.

38. Ghosh K, Thodeti CK, Dudley AC, Mammoto A, Klagsbrun M, Ingber DE. Tumor-derived endothelial cells exhibit aberrant Rho-mediated mechanosensing and abnormal angiogenesis in vitro. Proc Natl Acad Sci U S A. 2008;105(32):11305-11310. http://www.ncbi.nlm.nih.gov/pmc /articles/PMC2516246/?tool=pubmed. Accessed April 25, 2012.
39. Huang S, Ingber DE. A non-genetic basis for cancer progression and metastasis: self-organizing attractors in cell regulatory networks. Breast Dis. 2006;26:27-54. http://iospress.metapress .com/content/a0n04p7285718586/fulltext.html. Accessed April 25, 2012.

40. Huang S, Ingber DE. Cell tension, matrix mechanics, and cancer development. Cancer Cell. 2005;8(3):175-176. http://www.sciencedirect.com/science/article/pii /S1535610805002679. Accessed April 25, 2012.

41. Dike LE, Chen CS, Mrksich M, Tien J, Whitesides GM, Ingber DE. Geometric control of switching between growth, apoptosis, and differentiation during angiogenesis using micropatterned substrates. In Vitro Cell Dev Biol Anim. 1999;35(8):441-448.

42. Mammoto A, Ingber DE. Cytoskeletal control of growth and cell fate switching. Curr Opin Cell Biol. 2009;21(6):864-870.

43. Ingber DE. Mechanical control of tissue morphogenesis during embryological development. Int J Dev Biol. 2006;50(2-3):255-266.

44. Ingber DE, Levin M. What lies at the interface of regenerative medicine and developmental biology? Development. 2007;134(14):2541-2547. http://dev.biologists.org /content/134/14/2541.long. Accessed April 25, 2012.

45. Snelson KD. Continuous tension, discontinuous compression structures. US patent 3,169,611. February 16, 1965.

46. Connelly R, Back A. Mathematics and tensegrity. Am Scientist. 1998;86:142-151.

47. Robbie DL. Tensional forces in the human body Orthop Rev. 1977;6:45-48.

48. Ingber DE, Jamieson JD. Cells as tensegrity structures: architectural regulation of histodifferentiation by physical forces tranduced over basement membrane. In: Andersson LC, Gahmberg CG, Ekblom P, eds. Gene Expression During Normal and Malignant Differentiation. Orlando, FL: Academic Press; 1985:13-32.

49. Wang N, Tytell JD, Ingber DE. Mechanotransduction at a distance: mechanically coupling the extracellular matrix with the nucleus. Nat Rev Mol Cell Biol. 2009;10(1):75-82.

50. Maniotis AJ, Chen CS, Ingber DE. Demonstration of mechanical connections between integrins, cytoskeletal filaments, and nucleoplasm that stabilize nuclear structure. Proc Natl Acad Sci U S A. 1997;94(3):849-854. http://www.ncbi.nlm.nih.gov/pmc /articles/PMC19602/?tool=pubmed. Accessed April 25, 2012.

51. Wyss Institute created. Wyss Institute Newsroom. October 7, 2008. http://wyss.harvard.edu/viewpressrelease/11 /wyss-institute-created. Accessed October 5, 2011.

52. Lele TP, Sero JE, Matthews BD, et al. Tools to study cell mechanics and mechanotransduction. Methods Cell Biol. 2007;83:443-472.

53. Polte TR, Eichler GS, Wang N, Ingber DE. Extracellular matrix controls myosin light chain phosphorylation and cell contractility through modulation of cell shape and cytoskeletal prestress. Am J Physiol Cell Physiol. 2004;286(3):C518-C528. http://ajpcell .physiology.org/content/286/3/C518.long. Accessed April 25, 2012.

54. Stamenovic D, Coughlin MF. The role of prestress and architecture of the cytoskeleton and deformability of cytoskeletal filaments in mechanics of adherent cells: a quantitative analysis. $J$ Theor Biol. 1999;201(1):63-74. 
55. Jonas O, Duschl C. Force propagation and force generation in cells. Cytoskeleton (Hoboken). 2010;67(9):555-563.

56. Kumar S, Maxwell IZ, Heisterkamp A, et al. Viscoelastic retraction of single living stress fibers and its impact on cell shape, cytoskeletal organization, and extracellular matrix mechanics. Biophys J. 2006;90(10):3762-3773. http://www.ncbi.nlm.nih.gov/pmc/articles/PMC1440757 /?tool=pubmed. Accessed April 25, 2012.

57. Brangwynne CP, MacKintosh FC, Kumar S, et al. Microtubules can bear enhanced compressive loads in living cells because of lateral reinforcement. J Cell Biol. 2006;173(5):733-741. http://www.ncbi.nlm.nih.gov/pmc/articles/PMC2063890 /?tool=pubmed. Accessed April 25, 2012.

58. Matthews BD, Overby DR, Alenghat FJ, et al. Mechanical properties of individual focal adhesions probed with a magnetic microneedle. Biochem Biophys Res Commun. 2004;313(3):758-764.

59. Langevin HM, Bouffard NA, Badger GJ, latridis JC, Howe AK Dynamic fibroblast cytoskeletal response to subcutaneous tissue stretch ex vivo and in vivo. Am J Physiol Cell Physiol. 2005;288(3):C747-C756. http://ajpcell.physiology.org /content/288/3/C747.long. Accessed April 25, 2012.

60. Langevin HM, Storch KN, Snapp RR, et al. Tissue stretch induces nuclear remodeling in connective tissue fibroblasts. Histochem Cell Biol. 2010;133(4):405-415. http://www.ncbi.nlm.nih.gov/pmc /articles/PMC2880391/?tool=pubmed. Accessed April 25, 2012.

61. Sultan C, Stamenovic D, Ingber DE. A computational tensegrity model predicts dynamic rheological behaviors in living cells. Ann Biomed Eng. 2004;32(4):520-530.

62. Vera C, Skelton R, Bossens F, Sung LA. 3-D nanomechanics of an erythrocyte junctional complex in equibiaxial and anisotropic deformations. Ann Biomed Eng. 2005;33(10):1387-1404.

63. Luo Y, Xu X, Lele T, Kumar S, Ingber DE. A multi-modular tensegrity model of an actin stress fiber. $J$ Biomech. 2008;41(11):2379-2387. http://www.ncbi.nlm.nih.gov/pmc/articles /PMC2603623/?tool=pubmed. Accessed April 25, 2012.

64. Sitharam M, Agbandje-McKenna M. Modeling virus self-assembly pathways: avoiding dynamics using geometric constraint decomposition. J Comput Biol. 2006;13(6):1232-1265 http://online.liebertpub.com/doi/pdf/10.1089/cmb.2006.13.1232. Accessed April 25, 2012.

65. Tanaka S, Kerfeld CA, Sawaya MR, et al Atomic-level models of the bacterial carboxysome shell. Science. 2008;319(5866):1083-1086.

66. Zheng J, Birktoft JJ, Chen Y, et al. From molecular to macroscopic via the rational design of a self-assembled 3D DNA crystal. Nature. 2009;461(7260):74-77. http://www.ncbi.nlm.nih.gov/pmc/articles /PMC2764300/?tool=pubmed. Accessed April 25, 2012.

67. Ingber DE. Tensegrity and mechanotransduction. J Bodyw Mov Ther. 2008;12(3):198-200. http://www.ncbi.nlm .nih.gov/pmc/articles/PMC2614693/?tool=pubmed. Accessed April 25, 2012.

68. Wozniak MA, Chen CS. Mechanotransduction in development: a growing role for contractility. Nat Rev Mol Cell Biol. 2009;10(1):34-43. http://www.ncbi.nlm.nih.gov/pmc/articles /PMC2952188/?tool=pubmed. Accessed April 25, 2012.
69. Matthews BD, Overby DR, Mannix R, Ingber DE. Cellular adaptation to mechanical stress: role of integrins, Rho, cytoskeletal tension and mechanosensitive ion channels. J Cell Sci. 2006;119(pt 3):508-518. http://jcs.biologists.org /content/119/3/508.long. Accessed April 25, 2012.

70. Lele TP, Thodeti CK, Ingber DE. Force meets chemistry: analysis of mechanochemical conversion in focal adhesions using fluorescence recovery after photobleaching. J Cell Biochem. 2006;97(6):1175-1183. http://onlinelibrary.wiley .com/doi/10.1002/jcb.20761/pdf. Accessed April 25, 2012.

71. Geiger B, Spatz JP, Bershadsky AD. Environmental sensing through focal adhesions. Nat Rev Mol Cell Biol. 2009;10(1): 21-33.

72. Meyer CJ, Alenghat FJ, Rim P, Fong JH, Fabry B, Ingber DE. Mechanical control of cyclic AMP signalling and gene transcription through integrins. Nat Cell Biol. 2000;2(9):666-668.

73. Alenghat FJ, Tytell JD, Thodeti CK, Derrien A, Ingber DE. Mechanical control of CAMP signaling through integrins is mediated by the heterotrimeric Galphas protein. $J$ Cell Biochem. 2009;106(4):529-538. http://www.ncbi.nlm.nih.gov/pmc/articles /PMC2739599/?tool=pubmed. Accessed April 25, 2012.

74. Matthews BD, Thodeti CK, Tytell JD, Mammoto A, Overby DR, Ingber DE. Ultra-rapid activation of TRPV4 ion channels by mechanical forces applied to cell surface beta1 integrins. Integr Biol (Camb). 2010;2(9):435-442. http://www.ncbi.nlm.nih.gov/pmc /articles/PMC3147167/?tool=pubmed. Accessed April 25, 2012.

75. Thodeti CK, Matthews B, Ravi A, et al. TRPV4 channels mediate cyclic strain-induced endothelial cell reorientation through integrin-to-integrin signaling. Circ Res. 2009;104(9):1123-1130. http://www.ncbi.nlm.nih.gov/pmc/articles/ PMC2754067/?tool=pubmed. Accessed April 25, 2012.

76. McBeath R, Pirone DM, Nelson CM, Bhadriraju K, Chen CS. Cell shape, cytoskeletal tension, and $\mathrm{RhoA}$ regulate stem cell lineage commitment. Dev Cell. 2004;6(4):483-495. http://www.sciencedirect.com/science/article/pii /S1534580704000759. Accessed April 25, 2012.

77. Sanchez-Esteban J, Wang Y, Filardo EJ, Rubin LP, Ingber DE. Integrins $\beta 1, \alpha 6$, and $\alpha 3$ contribute to mechanical strain-induced differentiation of fetal lung type II epithelial cells via distinct mechanisms. Am J Physiol Lung Cell Mol Physiol. 2006;290(2):L343-L350. http://ajplung.physiology.org /content/290/2/L343.long. Accessed April 25, 2012.

78. Ingber DE. From cellular mechanotransduction to biologically inspired engineering: 2009 Pritzker Award Lecture, BMES Annual Meeting October 10, 2009. Ann Biomed Eng. 2010;38(3):1148-1161. http://www.ncbi.nlm.nih.gov/pmc/articles /PMC2913424/?tool=pubmed. Accessed April 25, 2012.

79. Ott HC, Clippinger B, Conrad C, et al. Regeneration and orthotopic transplantation of a bioartificial lung. Nat Med. 2010;16(8):927-933.

80. Ingber DE. Mechanobiology and diseases of mechanotransduction. Ann Med. 2003;35(8):564-577.

81. Nikkhah M, Strobl JS, De Vita R, Agah M. The cytoskeletal organization of breast carcinoma and fibroblast cells inside three dimensional (3-D) isotropic silicon microstructures. Biomaterials. 2010;31(16):4552-4561.

(continued) 
82. Mammoto A, Connor KM, Mammoto T, et al. A mechanosensitive transcriptional mechanism that controls angiogenesis. Nature. 2009;457(7233):1103-1108. http://www.ncbi.nlm.nih.gov/pmc /articles/PMC2708674/?tool=pubmed. Accessed April 25, 2012.

83. Still AT. The Philosophy and Mechanical Principles of Osteopathy. Kansas City, MO: Hudson-Kimberly Pub Co; 1902.

84. Cummings $\mathrm{CH}$. A tensegrity model for osteopathy in the cranial field. Am Acad Osteopath J. 1994;4(2):9-13,24-7.

85. Magoun $\mathrm{HI} J$ r. Structure and function reexamined [letter] J Am Osteopath Assoc. 2002;102(9):465-466. http://www.jaoa.org /content/102/9/465.long. Accessed April 25, 2012.

86. Kuchera ML. Osteopathic manipulative medicine considerations in patients with chronic pain. J Am Osteopath Assoc. 2005;105(9)(suppl 4):S29-S36. http://www.jaoa.org/content /105/suppl_4/S29.long. Accessed April 25, 2012.

87. Kuchera ML. Applying osteopathic principles to formulate treatment for patients with chronic pain. J Am Osteopath Assoc. 2007;107(10)(suppl 6):ES28-38. http://www.jaoa.org/content /107/suppl_6/ES28.long. Accessed April 25, 2012.

88. Mustafaraj E, Ellis JM, Dick-Perez RB, Klock GB, Hisley K. Investigation of lower extremity aggregate fascial $3 \mathrm{D}$ tissue geometry using visual mapping techniques and the visible human male image set [abstract S19]. J Am Osteopath Assoc. 2010;110(1):35.

89. Kuchera ML. Postural considerations in osteopathic diagnosis and treatment. In: Chila AG, executive ed. Foundations of Osteopathic Medicine. 3rd ed. Baltimore, MD: Lippincott Williams \& Wilkins; 2011:437-483.

90. Mason D. Glossary of osteopathic terminology. 2009 ed. In: Chila AG, executive ed. Foundations of Osteopathic Medicine. 3rd ed. Baltimore, MD: Lippincott Williams \& Wilkins; 2011:1087-1110

91. Dowling DJ, Scariati P. Myofascial release concepts. In: DiGiovanna EL, Schiowitz S, Dowling DJ, eds. An Osteopathic Approach to Diagnosis and Treatment. Philadelphia, PA: Lippincott Williams \& Wilkins; 2005:95-102.

92. O'Connell JA. Myofascial release approach. In: Chila AG, executive ed. Foundations of Osteopathic Medicine. 3rd ed. Baltimore, MD: Lippincott Williams \& Wilkins; 2011:682-727.

93. Willard FH, Fossum C, Standley PR. The fascial system of the body. In: Chila AG, executive ed. Foundations of Osteopathic Medicine. 3rd ed. Baltimore, MD: Lippincott Williams \& Wilkins; 2011:74-92.

94. Silver FH, Siperko LM, Seehra GP. Mechanobiology of force transduction in dermal tissue. Skin Res Technol. 2003;9(1):3-23.

95. Ross MH, Kaye GI, Pawlina W. Histology: A Text and Atlas, With Cell and Molecular Biology. Philadelphia, PA: Lippincott Williams \& Wilkins; 2003.

96. Tomasek JJ, Gabbiani G, Hinz B, Chaponnier C, Brown RA Myofibroblasts and mechano-regulation of connective tissue remodelling. Nat Rev Mol Cell Biol. 2002;3(5):349-363.

97. Langevin HM, Cornbrooks CJ, Taatjes DJ. Fibroblasts form a body-wide cellular network. Histochem Cell Biol. 2004;122(1):7-15.
98.Dodd JG, Good MM, Nguyen TL, Grigg AI, Batia LM, Standley PR. In vitro biophysical strain model for understanding mechanisms of osteopathic manipulative treatment. J Am Osteopath Assoc. 2006;106(3):157-166. http://www.jaoa.org/content/106/3/157.long Accessed April 25, 2012.

99.Meltzer KR, Cao TV, Schad JF, King H, Stoll ST, Standley PR. In vitro modeling of repetitive motion injury and myofascial release. J Bodyw Mov Ther. 2010;14(2):162-171. http://www.ncbi.nlm.nih .gov/pmc/articles/PMC2853774/?tool=pubmed. Accessed April 25, 2012.

100.Standley PR, Meltzer K. In vitro modeling of repetitive motion strain and manual medicine treatments: potential roles for pro- and anti-inflammatory cytokines. J Bodyw Mov Ther. 2008;12(3):201-203. http://www.ncbi.nlm.nih.gov/pmc/articles /PMC2622428/?tool=pubmed. Accessed April 25, 2012.

101. Meltzer KR, Standley PR. Modeled repetitive motion strain and indirect osteopathic manipulative techniques in regulation of human fibroblast proliferation and interleukin secretion. J Am Osteopath Assoc. 2007;107(12):527-536. http://www.jaoa.org /content/107/12/527.long. Accessed April 25, 2012.

102.Eagan TS, Meltzer KR, Standley PR. Importance of strain direction in regulating human fibroblast proliferation and cytokine secretion: a useful in vitro model for soft tissue injury and manual medicine treatments. J Manipulative Physiol Ther. 2007;30(8):584-592.

103.Bouffard NA, Cutroneo KR, Badger GJ, et al. Tissue stretch decreases soluble TGF- $\beta 1$ and type-1 procollagen in mouse subcutaneous connective tissue: evidence from ex vivo and in vivo models. J Cell Physiol. 2008;214(2):389-395. http://www.ncbi.nlm.nih.gov/pmc/articles/PMC3065715 /?tool=pubmed. Accessed April 25, 2012.

104.Storch KN, Taatjes DJ, Bouffard NA, Locknar S, Bishop NM, Langevin HM. Alpha smooth muscle actin distribution in cytoplasm and nuclear invaginations of connective tissue fibroblasts. Histochem Cell Biol. 2007;127(5):523-530.

105.Langevin HM, Storch KN, Cipolla MJ, White SL, Buttolph TR, Taatjes DJ. Fibroblast spreading induced by connective tissue stretch involves intracellular redistribution of $\alpha$ - and $\beta$-actin. Histochem Cell Biol. 2006;125(5):487-495.

106.Langevin HM, Bouffard NA, Badger GJ, Churchill DL, Howe AK. Subcutaneous tissue fibroblast cytoskeletal remodeling induced by acupuncture: evidence for a mechanotransduction-based mechanism. J Cell Physiol. 2006;207(3):767-774.

107. Schleip R, Klingler W, Lehmann-Horn F. Active fascial contractility: fascia may be able to contract in a smooth muscle-like manner and thereby influence musculoskeletal dynamics. Med Hypotheses. 2005;65(2):273-277.

108.Langevin HM, Bouffard NA, Fox JR, et al. Fibroblast cytoskeletal remodeling contributes to connective tissue tension. J Cell Physiol. 2011;226(5):1166-1175.

109.Still AT. Autobiography of A.T. Still. Kirksville, MO: published by the author; 1908. Reprinted, Indianapolis, IN: American Academy of Osteopathy; 2000. 